\title{
NASA lines up for a bigger slice of the biological research pie
}

[WASHINGTON] The US space agency NASA is bracing itself for the receipt by the end of this month of an avalanche of proposals from research groups wishing to join its new Astrobiology Institute for the interdisciplinary study of life in the Universe.

If successful, the experimental institute could take the agency's research activities beyond its traditional roots in fields such as astrophysics and planetary geology. This 'virtual institute' - which NASA planners envisage as a semi-independent network of organizations working on similar research problems around the country - will be 'hosted' by the Ames Research Center outside San Francisco, where a director and a few staff will provide computing and administrative support and overall programme direction.

The institute will pioneer techniques in scientific collaboration, using the next-generation Internet to let researchers collaborate via video links, and share expensive instruments and computer simulations. Funding for the first year will be about $\$ 7$ million, climbing to $\$ 8$ million next year and $\$ 10$ million thereafter. NASA says it is committed to the programme for "at least 20 years".

The scope of research at the Astrobiology Institute will be broad, ranging from investigation of the origin of life on Earth, through the question of how terrestrial ecosystems evolve to the search for life on other planets. The planners hope that the interdisciplinary study of these problems will, in effect, create a branch of science - astrobiology - whose exact definition is not yet established. "We don't really know what this field is going to be," says Gerald Soffen of the NASA Goddard Space Flight Center in Maryland, who has been asked by the agency's administrator Dan Goldin to help shape plans for astrobiology. Soffen was project scientist for the Viking Mars missions of the 1970s, and later served as the agency's director of life sciences.

Interest in the subject was stirred last year by the report of signs of fossil life in a martian meteorite. NASA and the National Science Foundation have already invested extra funds for research on life in extreme environments on Earth and NASA is to introduce a research programme in evolutionary biology this year, with $\$ 4$ million going to individual scientists working on questions of life's origins.

The Astrobiology Institute has strong support from Goldin, who has been pushing NASA to beef up its biology programme for more than a year (see Nature 384, 601; 1996). Goldin has made a point recently of meeting biologists, including David Baltimore, the new president of the California Institute of Technology.

The relative wealth and political support enjoyed by the biological sciences is one reason for NASA's interest in the field. But Goldin also wants his agency to be a leader in technological innovations such as computers based on DNA's ability to organize information, and the creation of autonomous, 'think-

\section{India and United States to share satellite data}

[NEW DELHI] After more than a decade of refusing to do so, India has agreed to share with the United States weather and atmospheric data gathered by its INSAT geostationary satellites over the Indian Ocean on a "near real-time basis". But it has stipulated that the United States should not disseminate the Indian data to a third country without its consent.

India has three INSAT satellites collecting data, with a resolution of $2.75 \mathrm{~km}$ in the visible band and $11 \mathrm{~km}$ in the infrared. INSAT-2E, to be launched this year, will have improved resolution, as well as the ability to measure atmospheric moisture.

The agreement, signed

last week in Washington, represents a victory for US scientists, who have been pressing since 1987 for access to INSAT data to help them fill a data gap over the Indian Ocean.

The latest agreement reached after intense negotiations between NASA and the Indian Department of Space (see Nature 375, 441; 1995) - marks a policy shift that ends a long-standing irritant in Indo-American scientific collaboration.

Under the agreement, initially planned for five years, NASA and the US National Oceanic and Atmospheric
Administration (NOAA) can access high-resolution processed INSAT data via a dedicated link between NASA in Washington DC and IMD in New Delhi.

Processing involves only a few seconds, so US agencies will receive INSAT data in "near real time", says an IMD official. India is to get direct access to NASA's

Earth and atmosphere science databases, including data from NOAA's Geostationary Operational Environmental Satellites (GOES) over the Pacific Ocean. IMD says this would help to sharpen its forecasts of monsoons and tropical cyclones.

K.S. Jayaraman

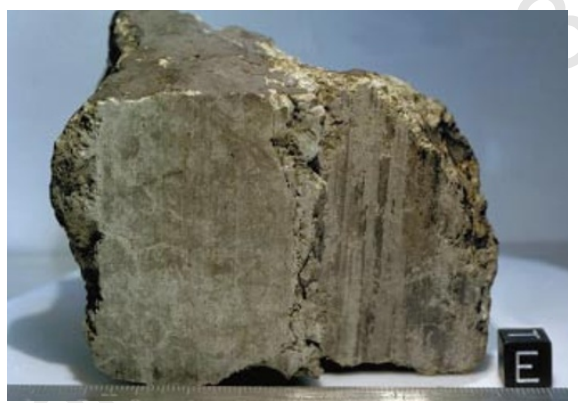

Hard evidence: this martian rock has already had a major influence on thinking at NASA.

ing spacecraft' based on biological principles.

Today, Goldin says, NASA doesn't have the "intellectual underpinnings" for such work. "The biological revolution has passed the space program by," he lamented last month at a meeting of NASA's external advisory council. Goldin's answer is to raise both the profile and the number of biologists in NASA. He hopes to hire a biologist as the agency's next chief scientist, a hitherto mostly symbolic post that has been vacant for months.

Goldin also told the advisory council he would like to see spending on the Astrobiology Institute eventually reach $\$ 100$ million a year. "You just wait for the screaming from the physical scientists [when that happens]," he said.

But the institute will start modestly. NASA hopes to pick between seven and ten institute partners in April, who will receive funding for three to five years. Michael Meyer, astrobiology discipline scientist at NASA headquarters, says the primary reason for choosing institutional members rather than simply funding individual researchers is to take advantage of the interdisciplinary links that member organizations such as universities will bring with them. Institute members are also expected to contribute resources beyond the funding that NASA provides.

Although the NASA advisory council supports the institute as a worthwhile experiment, some members at last month's meeting expressed unease about the concept's lack of definition. Many believe success will depend heavily on the leadership of the institute's director, who has yet to be chosen. Soffen says the agency is searching for a "non-NASA person who has a vision".

Interest already seems high in the research community. NASA received more than 70 letters of intent to respond to the solicitation for institute members. That prompted Soffen to worry that the agency will not have enough money to satisfy the demand. "It kind of worries me what we turned on," he said.

Tony Reichhardt 